
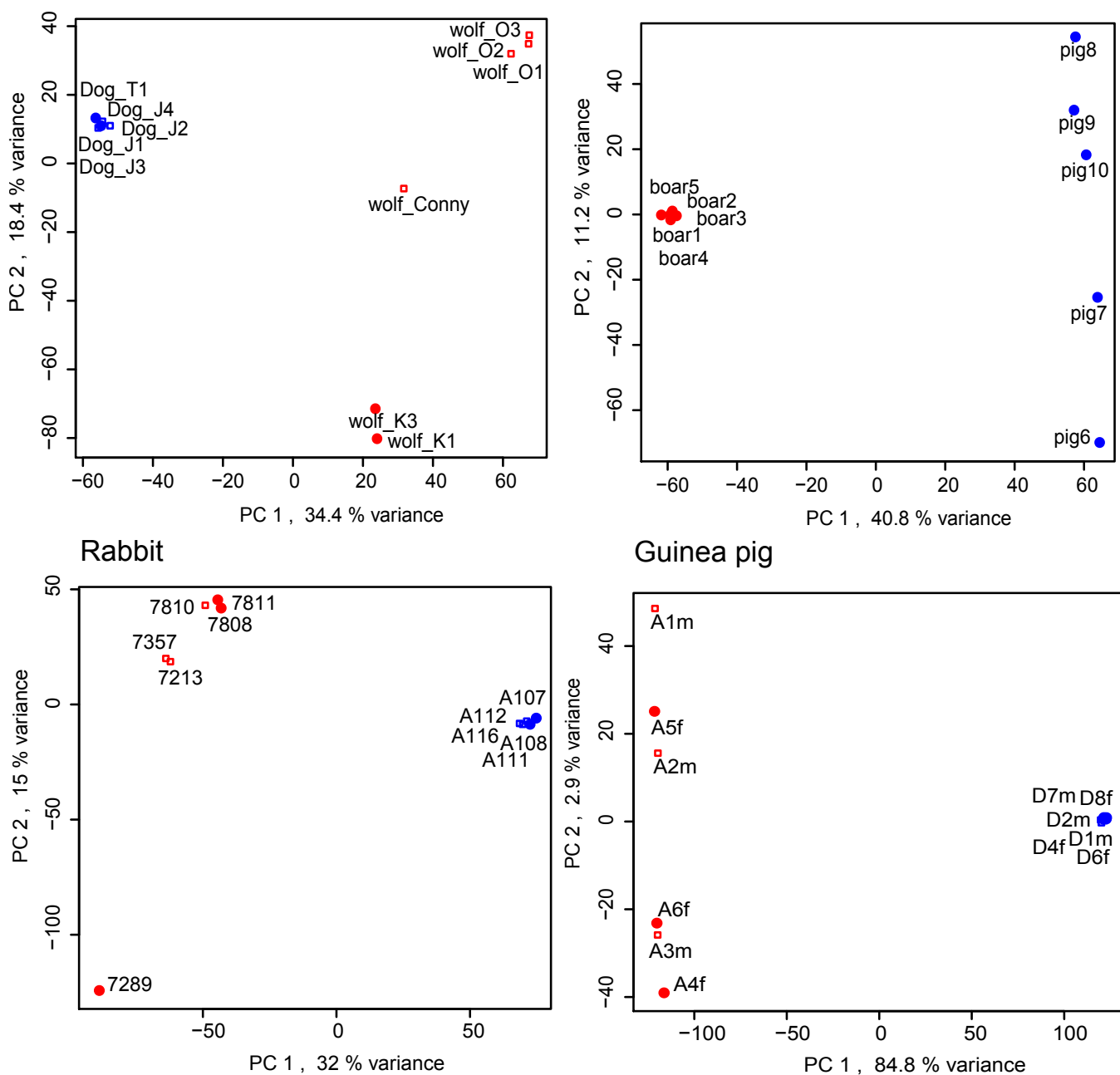

\title{
Guinea pig
}

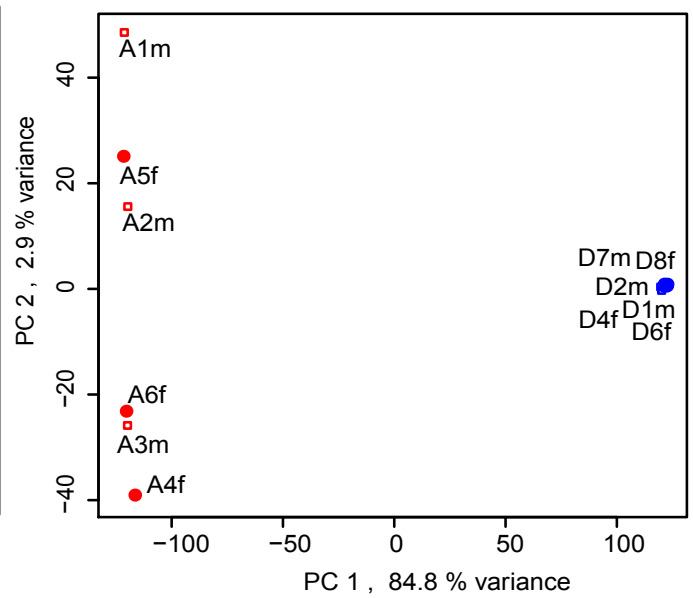

Rat

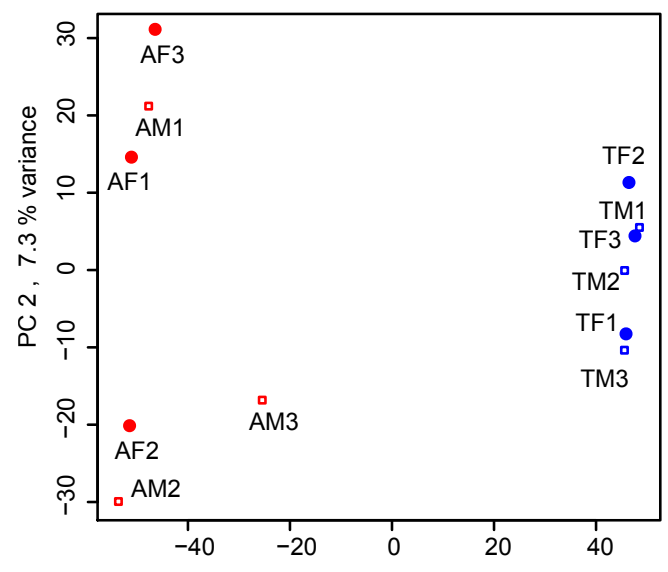

PC 1, $54.4 \%$ variance 